\title{
Comparative Investigation of Glutathione S-transferase (GST) in Different Crops and Purification of High Active GSTs from Onion (Allium cepa L.)
}

\author{
Md. Raisul Islam ${ }^{1,2}$, Abul Kashem Chowdhury ${ }^{2}$, Md. Mahfuzur Rahman ${ }^{1}$, Md. Motiar Rohman ${ }^{1}$ \\ ${ }^{1}$ Molecular Breeding Lab, Bangladesh Agricultural Research Institute, Gazipur, Bangladesh \\ ${ }^{2}$ Department of Genetics and Plant Breeding, Patuakhali Science and Technology University, Patuakhali, Bangladesh
}

Email address:

evanagpstu02@gmail.com (Md. R. Islam), kashempstu@yahoo.com (A. K. Chowdhury), r.gitla@gmail.com (Md. M. Rahman), motiar_1@yahoo.com (Md. M. Rohman)

\section{To cite this article:}

Md. Raisul Islam, Abul Kashem Chowdhury, Md. Mahfuzur Rahman, Md. Motiar Rohman. Comparative Investigation of Glutathione $S$-transferase (GST) in Different Crops and Purification of High Active GSTs from Onion (Allium cepa L.). Journal of Plant Sciences. Vol. 3, No. 3, 2015, pp. 162-170. doi: 10.11648/j.jps.20150303.17

\begin{abstract}
Glutathione $S$-transferases (GSTs; EC 2.5.1.18) are abundant proteins encoded by a highly divergent ancient gene family with protective functions through detoxification and non-catalytic roles as carriers of cytotoxins. In this work, we investigated the GST activities in seedlings of 38 crops to obtain a plant with high active GST for further study. In screening of 38 crops, onion seedling showed the highest GST activity (483.54 nmol min $\mathrm{mg}^{-1}$ protein) followed by wheat(372.89 nmol $\mathrm{min}^{-1} \mathrm{mg}^{-1}$ protein), barley (253.44 nmol min $\mathrm{mg}^{-1}$ protein), rice (244.12 $\mathrm{nmol} \mathrm{min} \mathrm{mg}^{-1} \mathrm{protein}^{-1}$ and proso millet (173.34 nmol min $\mathrm{mg}^{-1}$ protein). Carrot seedling showed the lowest activity (3.63 nmol min $\mathrm{mg}^{-1}$ protein).In onion plants, both root and leaf showed high GST activity. Onion bulb GSTs were separated DEAE cellulose column chromatography, and purified by affinity chromatography ( $S$-hexyl glutathione-agarose). Three GST peaks were found to elute at 67,107 and $140 \mathrm{mM}$ of $\mathrm{KCl}$ gradient solution, and were named as GSTa, GSTb and GSTc. Among the three GSTs, GSTa, GSTb and GSTc contained 9.58, 61.45 and $28.97 \%$ of total activity, respectively. In purification, GSTa, GSTb and GSTc had specific activities of 9075,17259 and $19868 \mathrm{nmol} \mathrm{min} \mathrm{mg}^{-1}$ protein, respectively, along with yield of 2.48, 3.17 and 1.28, and purification fold of $15.8,29.9$ and 34.5 , respectively. The purity and molecular mass of the fraction was examined by SDS-PAGE. The silver staining of the purified GSTa, GSTb and GSTc indicated that final product of GSTb and GSTc were highly purified and migrated as a single band on SDS-PAGE with an apparent molecular mass of $27 \mathrm{kDa}$. However, GSTa eluted with Glyoxalase-I (Gly-I) and to purify GSTa, more methodological application are suggested.
\end{abstract}

Keywords: Comparative GST, Crops, Purification, High Active GST, Onion

\section{Introduction}

Glutathione $S$-transferases (GSTs; EC 2.5.1.18), a protein family of multiple function, catalyze the transfer of the tripeptide glutathione ( $\gamma$-glutamyl-cysteinyl-glycine; GSH) to a co-substrate containing a reactive electrophilic center to form a polar $S$-glutathionylated reaction product [1]. In plant, GSTs are potential in modifying xenobiotics by glutathionation and the reaction is rapidly induced by their substrates mostly plant herbicides [2]. GSTs play essential role in different physiological processes such as stress responses, reduction of organic hydrogen peroxides and isomerization of specific metabolites [1], binding of auxin [3], cytokinin [4], and UV light depended signal transduction [5].
These enzymes were first discovered in animals in the 1960s as a result of their importance in the metabolism and detoxification of drugs. Since that time, GST activities, or the corresponding enzymes or gene sequences, have been identified in all animals, plants and fungi analyzed $[6,7]$.

Due to climate change, plant frequently exposes to different environmental stresses such as salinity, drought, heat, cold, light and other adverse conditions. Under abiotic stress, different endogenous cytotoxic compounds are produced in plants and the cells are not safe until they are sequestrated into vacuole [6, 8]. Under abiotic stress, Plants under oxidative stress, reactive oxygen species (ROS) are produced in both radical $\left(\mathrm{O}_{2}^{-}, \mathrm{OH}, \mathrm{OH}_{2}^{-}\right)$and non-radical $\left(\mathrm{H}_{2} \mathrm{O}_{2}\right)$ forms. ROS causes cellular damage to metabolic 
disorders and senescence processes, structural and functional loss of cell organelles, and ultimately cause plant death [9]. GSTs have important role in protecting plant cells from toxic effect through detoxification or instead of catalyzing conjugate reactions, some GSTs may have antioxidative functions [10].

The GST family in plants is notable for its structural and functional diversity and the biochemical and physiological functions. Their classification and evolution have been reported by Mohsenzadeh et al. [7] and Dixon et al. [6]. Many of the GST members of remain to be elucidated. However, there are unexplored plant species to search new GSTs. Studied of GSTs in a large number of plant species together might provide comparative GST levels in different plants and also helps to find unexplored plant species with high active GST which might have detoxification as well as antioxidative roles in cell. However, report on comparative GST study in wide number of crops is rare. Therefore, in this study, we compared GST activities in 38 importance crops. Here, the GSTs were purified from plant with the highest level of GST activity.

\section{Materials and Methods}

\subsection{Plant Materials}

Fifteen days old seedlings of 38 different crops (except millets, 30 days) (Table1) were grown in plastic pot under greenhouse conditions. Whole seedlings were used in comparative study of GST. For comparative GST activities in plant parts, mature onion plants were used and for purification of GSTs, onion bulbs were selected.

Table 1. List of crops studied for GST activities.

\begin{tabular}{|c|c|c|c|}
\hline Sl. No. & Crop & Sl. No. & Crop \\
\hline 1. & Carrot (Daucus carota) advanced lineCr0021 & 20. & Chick pea (Cicerar ietinum cv BARI Chick pea-6) \\
\hline 2. & Sweet potato (Ipomea batatus cv BARI Sweet Potato-8) & 21. & Cowpea (Vigna unguiculata cv BARI Cowpea-1) \\
\hline 3. & Potato (Solanum tuberosum cv BARI Potao-30) & 22. & Lentil (Lens culinaris cv BARI Lentil-2) \\
\hline 4. & Ginger (Zingiber officinale cv BARI Ginger-1) & 23. & Safflower (Carthamus tinctorius cv BARI Safflower-1) \\
\hline 5. & Turmeric (Curcuma longa cv BARI Turmeric-3) & 24. & Sunflower (Helianthus annuus cv BARI Sunflower-2) \\
\hline 6. & Bottle gourd (Lagenaria siceraria cv BARI Bottle gourd-4) & 25. & Ground nut (Arachis hypogaea cv BARI Ground nut-8) \\
\hline 8. & Garlic (Allium sativum cv BARI Garlic-2) & 27. & Brassica juncea cv BARI Sarisha-11 \\
\hline 9. & Pumpkin (Cucurbita moschata cv BARI Pumpkin-2) & 28. & B. napus cv BARI Sarisha-13 \\
\hline 10. & Lettuce (Lactuca sativa cv BARI Lettuce-1)) & 29. & B. rapa cv BARI Sarisha- 14 \\
\hline 11. & Cauliflower (Brassica oleracea var Botrytis cv Rupa) & 30. & Sesame (Sesamum indicum cv BARISesame-1) \\
\hline 12. & Capsicum (Capsicum annuum cv BARI Capsicum-1) & 31. & Niger (Guozotia abyssinica cv Shova) \\
\hline 13. & Tomato (Solanum lycopersicum cv BARI Tomato-8) & 32. & Linseed (Linumus itatissimum cv Nila) \\
\hline 14. & Bringal (Solanum melongena cv Kazla) & 33. & Rice (Oriza sativa cv BRRIDhan-47)) \\
\hline 15. & Cabbage (Brassica oleracea var. capitata cv BARI Cabbage-2) & 34. & Wheat (Triticum aestivum cv Prodip) \\
\hline 16. & Mung bean (Vigna radiate cv BARI Mug-6) & 35. & Maize (Zea mays cv BARI Hybrid Maize-7) \\
\hline 17. & Pea (Pisum sativum cv BARI Field pea-1) & 36. & Barley (Hordeum vulgare cv BARI Barley-3) \\
\hline 18. & Grass pea (Lathyrus sativus cv BARI Grasspea-2) & 37. & Foxtail millet (Setaria italica cv BARI Foxtail millet-3) \\
\hline 19. & Black gram (Vigna mungo cv BARI Blackgram-2) & 38 & Proso millet (Panicum miliaceum cv Tushar) \\
\hline
\end{tabular}

\subsection{Preparation of Soluble Protein}

Soluble proteins were extracted from different plant materials by homogenizing 5 gmof sample in an equal volume of $25 \mathrm{mM}$ Tris-HCl buffer ( $\mathrm{pH} 8.0$ ) containing $1 \mathrm{mM}$ EDTA, $1 \%(\mathrm{w} / \mathrm{v})$ ascorbate and $10 \%(\mathrm{w} / \mathrm{v})$ glycerol with mortar and pestle. The homogenates were centrifuged at 11,500 $\mathrm{x} g$ for $15 \mathrm{~min}$, and the supernatant was used as soluble protein solution.

\subsection{Extraction of Crude Protein for GST Purification}

One hundred and fifty gm of onion bulb tissues were homogenized in an equal volume of $25 \mathrm{mM}$ Tris-HCl buffer (pH 8.0) containing $1 \mathrm{mM}$ EDTA, $1 \%(\mathrm{w} / \mathrm{v})$ ascorbate and $10 \%$ $(\mathrm{w} / \mathrm{v})$ glycerol with Warming blender. The homogenates squeezed in a nylon cloth and was centrifuged at 11,500 $\mathrm{xg}$ for $15 \mathrm{~min}$, and the supernatant was used as soluble protein solution.

\subsection{Purification of Glutathione S-transferase}

\subsubsection{Anion Exchange Chromatography}

Proteins were precipitated from the soluble protein by ammonium sulfate at $65 \%$ saturation from the supernatant and centrifuged at $11,500 \times g$ for 10 minutes. The proteins were dialyzed against $10 \mathrm{mM}$ Tris- $\mathrm{HCl}$ buffer $(\mathrm{pH}$ 8) containing $0.01 \%(\mathrm{w} / \mathrm{v}) \beta$-mercaptoethanol and $1 \mathrm{mM}$ EDTA (buffer A) overnight to completely remove low molecular inhibitors. The dialyze was applied to a column $(1.77 \mathrm{~cm}$ i.d. $\times 20 \mathrm{~cm}$ ) of DEAE-cellulose (DE-52, Whatman, UK) that had been equilibrated with buffer $\mathrm{A}$ and eluted with a linear gradient of 0 to $0.4 \mathrm{M} \mathrm{KCl}$ in $750 \mathrm{ml}$ of buffer A. The GST activity and absorbance $\left(\mathrm{A}_{280}\right)$ were taken. The high active eluted peak at around $100 \mathrm{mM} \mathrm{KCl}$ was collected for further purification.

\subsubsection{Hydroxylapatite Chromatography}

High active GST pool GSTa was applied on a 
hydroxylapatite chromatography and eluted with linear gradient of 0-20 mM Potassium phosphate (K-P) buffer. Total 70 fractions, each containing $5 \mathrm{ml}$, were collected. The GST activity and absorbance $\left(\mathrm{A}_{280}\right)$ were taken.

\subsubsection{Affinity Chromatography}

The collected sample was applied to a column $(0.76 \mathrm{~cm}$ i.d. $\times 4.0 \mathrm{~cm}$ ) of $S$-hexylglutathione-agarose that had been equilibrated with $10 \mathrm{mM}$ Tris-HCl buffer ( $\mathrm{pH} 8.0)$ containing $0.01 \%(\mathrm{v} / \mathrm{v}) \beta$-mercaptoethanol (buffer B). The column was washed with buffer $\mathrm{B}$ containing $0.2 \mathrm{M} \mathrm{KCl}$ and eluted with buffer B containing $1.2 \mathrm{mM} S$-hexylglutathione. The high active protein fractions eluted with $S$-hexyl glutathione were combined and dialyzed against buffer $\mathrm{B}$, and the dialyze was used as the purified GST. The activity and absorbance $\left(\mathrm{A}_{280}\right)$ were taken.

\subsection{Enzyme Activity Assay}

Glutathione $\quad S$-transferase was assayed spectrophotometrically (Shimadzu, UV-1800) following the methods of Rohman et al.[11]. The reaction mixture contained $50 \mathrm{mM}$ (K-P) buffer (pH 6.5), $1.5 \mathrm{mM}$ GSH, 1 $\mathrm{mM}$ 1-chlro-2,4-dinitrobenzene (CDNB) and enzyme solution in a final volume of $0.70 \mathrm{ml}$. The enzyme reaction was initiated by the addition of CDNB, and the increase in absorbance was measured at $340 \mathrm{~nm}$ for $1 \mathrm{~min}$. The activity was calculated using the extinction coefficient of $9.6 \mathrm{mM}^{-}$ ${ }^{1} \mathrm{~cm}^{-1}$.

Glyoxalase I (Gly-I, EC: 4.4.1.5) activity was assayed out according to Hossain and Fujita [12]. Briefly, the assay mixture contained $100 \mathrm{mM} \mathrm{K}-\mathrm{P}$ buffer (pH 7.0), $15 \mathrm{mM}$ magnesium sulphate, $0.25 \mathrm{mM}$ reduced glutathione, and 3.5 $\mathrm{mM}$ methylglyoxal (MG) in a final volume of $0.8 \mathrm{ml}$. The reaction was started by the addition of $\mathrm{MG}$, and the increase in absorbance was recorded at $240 \mathrm{~nm}$ for $1 \mathrm{~min}$. The activity was calculated using the extinction coefficient of $3.37 \mathrm{mM}^{-1}$ $\mathrm{cm}^{-1}$.

\subsection{Protein Quantification}

Protein concentration was estimated following the method of Bradford [13] using BSA as protein standard.

\subsection{SDS-PAGE and Silver Staining}

To check the homogeneity of purified GST enzyme and to estimate its molecular mass, SDS-PAGE was done in $12.5 \%$ $(\mathrm{w} / \mathrm{v})$ gel containing $0.1 \%(\mathrm{w} / \mathrm{v})$ SDS by the method of Laemmli [14] followed by silver staining.

\subsection{Measurement of Molecular Weight}

The molecular weight was measured by gel documentation system (Alpha-Inotech).

\subsection{Statistical Analysis}

Data of GST level were analyzed by Statistical Analysis System (SAS (Version 9.3, SAS Institute Inc, NC, USA) following Complete Randomize Design (CRD). Means were separated by Tukey's range test and $\mathrm{P}<0.05$ was considered as significant level.

\section{Results and Discussion}

\subsection{Comparative Investigation of GST Activities in Different Crops}

To obtain a crop with very high active GST, firstly, 38 crops were examined (Table 1). The specific activities of GST towards model substrate CDNB in the soluble protein extracts of seedlings of carrot, sweet potato, potato, ginger, turmeric, bottle gourd, onion, garlic, pumpkin, lettuce, cauliflower, capsicum, tomato, bringal, cabbage, mung bean, pea, grass pea, black gram, chick pea, cow pea, lentil, safflower, sunflower, ground nut, soybean, three rape seeds, sesame, niger, linseed, rice, wheat, maize, barely, foxtail millet and proso millet are presented in Fig. 2. The activities of GST were found in all crops and among which, onion seedlings showed the highest GST activity (483.54 $\mathrm{nmol} \mathrm{min}$ ${ }^{1} \mathrm{mg}^{-1}$ protein) followed by wheat $\left(372.89 \mathrm{nmolmin}^{-1} \mathrm{mg}^{-1}\right.$

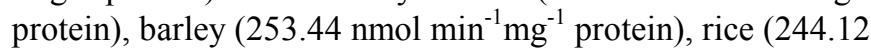
nmol min $\mathrm{mg}^{-1}$ protein), proso millet (173.34 nmol min $\mathrm{mg}^{-1}$

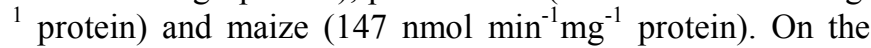
contrary, carrot showed the lowest activity $(3.63 \mathrm{nmol} \mathrm{min}$ ${ }^{1} \mathrm{mg}^{-1}$ protein) followed by tomato (15.01 nmol ${ }^{-1} \mathrm{~min}^{-1} \mathrm{mg}$

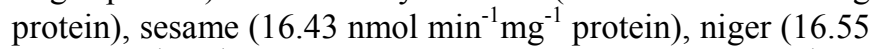
nmol $\mathrm{min}^{-1} \mathrm{mg}^{-1}$ protein) and sunflower $\left(16.85 \mathrm{nmol} \mathrm{min}^{-1} \mathrm{mg}^{-}\right.$ ${ }^{1}$ protein).

Plant GSTs are mainly involved in stress responses including GSH-conjugation in the metabolic detoxification of herbicides and natural products and GSH-dependent peroxidase reactions that protect cell components from oxidative damage by scavenging toxic organic hydroperoxides. In addition, plant GSTs play a role in GSHdependent thioltransferase that safeguards protein function from oxidative damage, and are also involved in dehydroascorbate reductase (DHAR) that functions in redox homeostasis [9]. Moreover, plant GSTs serves as ligands orbinding proteins for phytohormones (including auxins and cytokinins) or anthocyanins, thereby facilitating their transport and distribution in plants. Finally, plant GSTs play an indirect role in the regulation of apoptosis and in stress signaling pathways $[1,6,15,16]$. Therefore, GSTs are involved in stress tolerance mechanism of plants, and are required for the characterization of plant tolerance to stresses. Previous studies have demonstrated that plant GSTs can be differentially regulated by different abiotic stress factors, such as herbicides $[17,18)$, hydrogen peroxide $\left(\mathrm{H}_{2} \mathrm{O}_{2}\right)$ [19], dehydration [20, 21, 22], ultraviolet(UV) light [22], cold[18, 23, 24, 25], phosphate starvation [26], ozone exposure [27], high temperature [24, 28, 29], high salt and hormone treatments such as ethylene [30], auxin [31], methyl jasmonate, salicylic acid [32] and abscisic acid [33].Plant GSTs play an important role in various stress responses. Recently GST activity has been reported to increase in a number of crops under drought and saline stresses [34-37]. In 
this study, onion seedlings showed the highest activity (Fig. 1). Onion GSTs were previously reported in Japanese onion by Rohman et al. [11, 38] where five GST peaks eluted from ion exchange chromatography and among them a Phi type GST was reported with its function regarding legand binding and salinity drought and cold tolerance. On the other hand, another Allium crop garlic has been used to study GST in animal health, however, role of garlic GST has not been studied the biological role of GST in garlic plants under normal and abiotic stresses. Similarly, ginger and turmeric have been reported to regulate GSTs in animal bodies, but information on their GST is not available. In the cereals, wheat showed the highest activity followed by barley, rice, proso millet and maize where foxtail millet showed the minimum activity (Fig. 1). The detoxification and antioxidant activity of GSTs in barley has been reported by Rezaei et al. [39]. Rice GSTs have been reported with biological role in detoxification of xenobiotic and abiotic stress tolerance [40, 41] in transgenic plants. Wheat GST also reported to detoxification and antioxidant activities [17, 42-44). On the other hand, maize GST has been extensive studied for detoxification and transportation role [42, 45]. Recently, maize GST has been reported under abiotic stress like salinity [37] drought [46], cadmium and other stress [47]. However, proso millet which showed considerable GST activity has not been reported. Since proso millet can be grown under water stress condition, its GST might play important role under drought and other abiotic stress.

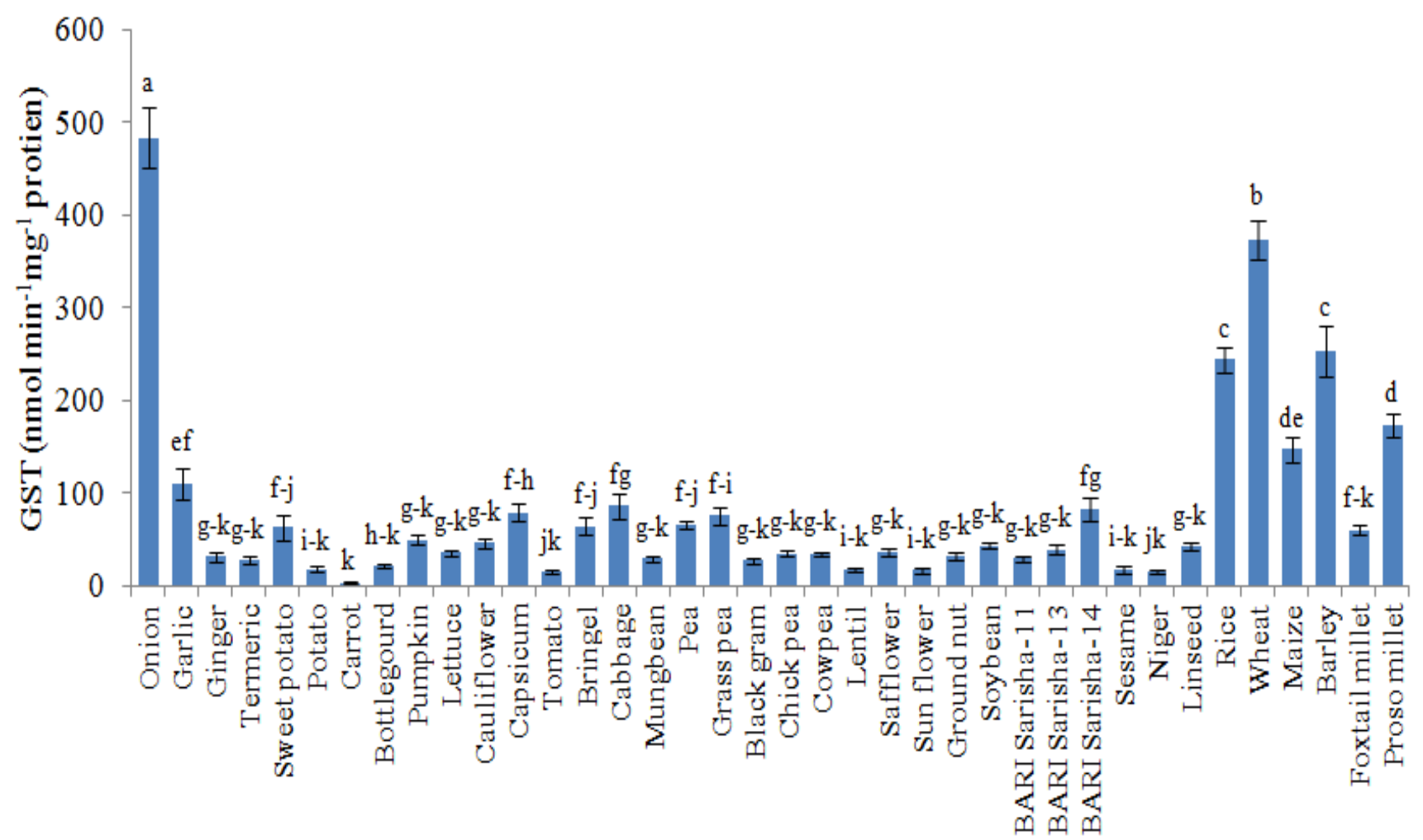

Fig. 1. Comparative activity of GST in the seedlings of different crops towards model substrate CDNB. The bars present the mean value of three independent experiments with three replications \pm standard error. Mean values in bars with similar letter between the bars are not significantly different at P $<0.05$.

In this study, seven oil crops were incorporated among them three rape seed species viz. BARI Sarisha11, 13 and 14 from Brassica juncea, B. napus and $B$. rapa, respectively (Fig. 1). The GST activities ranged 16.43-83.17 $\mathrm{nmol} \mathrm{min}^{-1}$ $\mathrm{mg}^{-1}$ protein and BARI Sarisha-14 belonging to Brassica rapa the highest GST activity $\left(83.16 \mathrm{nmol} \mathrm{min}^{-1} \mathrm{mg}^{-1}\right.$ protein).GST activity has been reported in to increase under biotic and abiotic stress in Brassica spp [48, 49], in safflower [50], in soybean [51, 52]. Role of GST also reported for root nodule formation in soybean [53].On the other hand role of GST has been reported in sunflower under biotic stress (However, role of GST has not yet been reported for oil crop like sunflower sesame, linseed and niger though, they contains some medical values.. Therefore, some of them might have GST with important biological role under normal and abiotic stress condition. The GST activities in pulse crops range $18.04-75.93 \mathrm{nmol} \mathrm{min}{ }^{-1} \mathrm{mg}^{-1}$ protein) and among them grass pea showed the highest activity $75.93 \mathrm{nmol} \mathrm{min}^{-1}$ $\mathrm{mg}^{-1}$ protein followed by pea (66.19 $\mathrm{nmol} \mathrm{min} \mathrm{mg}^{-1}$ protein) and interestingly induced GST activities have been reported in both the crops under Cd stress [54, 55].On the other hand, GST activity in mung bean has been studied in different abiotic stress [56, 57]. Molla et al. [58] compared GST activities of some lentil and mung beans, where they found higher GST activity in some lentil cultivars, where they found higher GST activity in lentil. In this study, mung bean seedlings showed higher activity compared to lentil seedlings. It might be due to using different variety. A cow pea GST has been reported to be responsive under drought stress [59]. However, report on GST in Chick pea, black gram and pea 
has been not found. All of the vegetable crops showed GST activities ranged 3.63-85.98 nmol min $\mathrm{mg}^{-1}$ protein, among which carrot had the least activity (Fig. 1). Among the vegetable crops studied, pumpkin GSTs have been extensively studied and three GSTs have been reported with their biological role $[60,61]$. Among other crops, report on a potato GST [62] and tomato GST [63, 64] were found. On the other hand, the activities of cabbage under molybdenum [65] and sweet potato GSTs with trypsin inhibitor [66] were reported to be regulated. Nevertheless, reports on GST in carrot, bottle gourd, lettuce, cauliflower, capsicum and brinjal are not available, though many of them are used to regulate GSTs in animals. Therefore, they might contain GSTs with important interaction with the compound(s) present in respective crops as well as important physiological roles under abiotic and biotic stress.

\subsection{GST Activity in Different Parts of Onion Plant}

Since onion seedlings exhibited the highest GST activity, an attempt was taken to purify GSTs from onion. Before that, GST activities were examined in different parts of onion plants, and it was observed that onion root showed the highest activity (781 nmol min $\mathrm{mg}^{-1}$ protein) followed by bulb (532 nmol min $\mathrm{mg}^{-1}$ protein) (Fig. 2). The leaves of the seedlings had the lowest activity (nmol $\mathrm{min}^{-1} \mathrm{mg}^{-1}$ protein). It might be due to presence of photosynthetic protein in leaves. On the other hand, the highest activity in root is not clear, and it might be due to growing environment [67]. The high GST activity in bulb is still ambiguous. However, one of the causes might be due to its regulation of physiological substrates [38]. However, due to easy availability, onion bulb was selected as plant material for purification of GST.

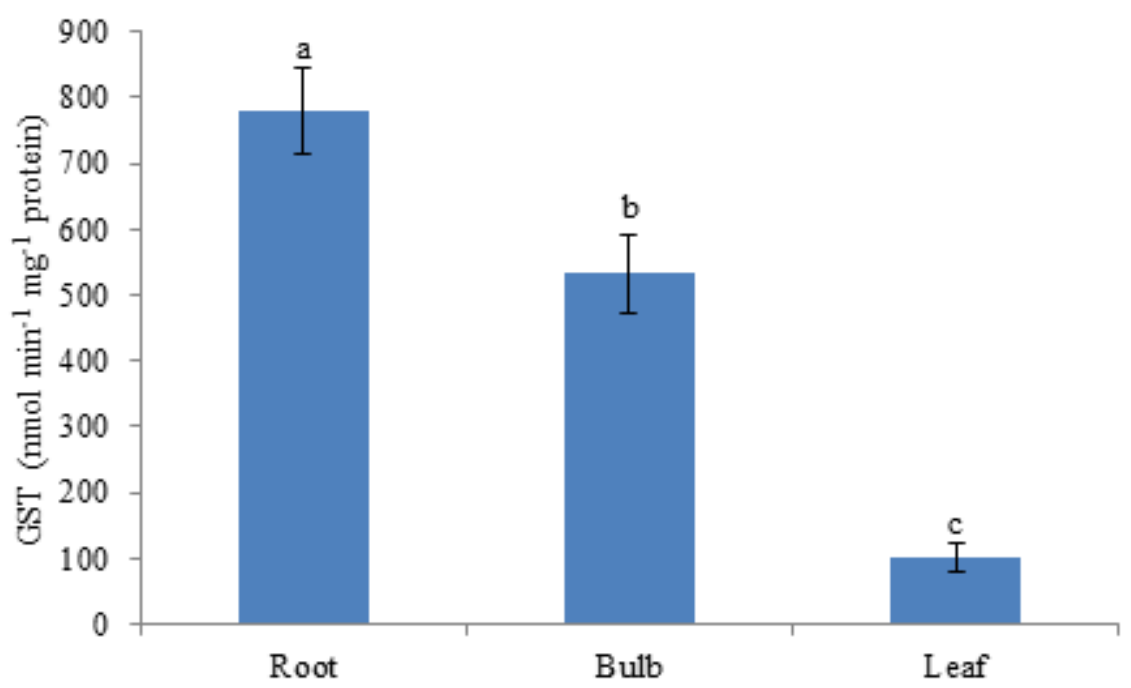

Fig. 2. GST activities in different parts of onion seedlings. The bars present the mean value of three independent experiments \pm standard error. Mean values in bars with similar letter between the bars are not significantly different at $P<0.05$.

\subsection{Purification of Onion GST}

Cloning and characterization of plant GSTs may be helpful in knowing the stress tolerance mechanism and improvement of plant stress tolerance by molecular breeding approach. As first step of cloning and characterization, this study separated and purified GSTs from onion bulb tissues. Soluble protein were extracted from $150 \mathrm{~g}$ onion bulb tissue and protein was precipitated with $65 \%\left(\mathrm{NH}_{4}\right)_{2} \mathrm{SO}_{4}$ and dialyzed over night in buffer A. The dialyze was applied on DEAE-cellulose column chromatography (i.d. $1.7 \times 20 \mathrm{~cm}$ ) and eluted with a liner gradient of $\mathrm{KCl}$ (0-0.2 M) (Fig. 3). Total 140 fractions, each containing $5 \mathrm{ml}$, were collected. The GST activities of each fraction towards model substrate CDNB and absorbance at $280 \mathrm{~nm}$ were measured. Three GST peaks eluted at 67,104 and $140 \mathrm{mM}$ of $\mathrm{KCl}$ were named as GSTa, GSTb and GSTc, respectively (Fig. 3 and Table 2). 


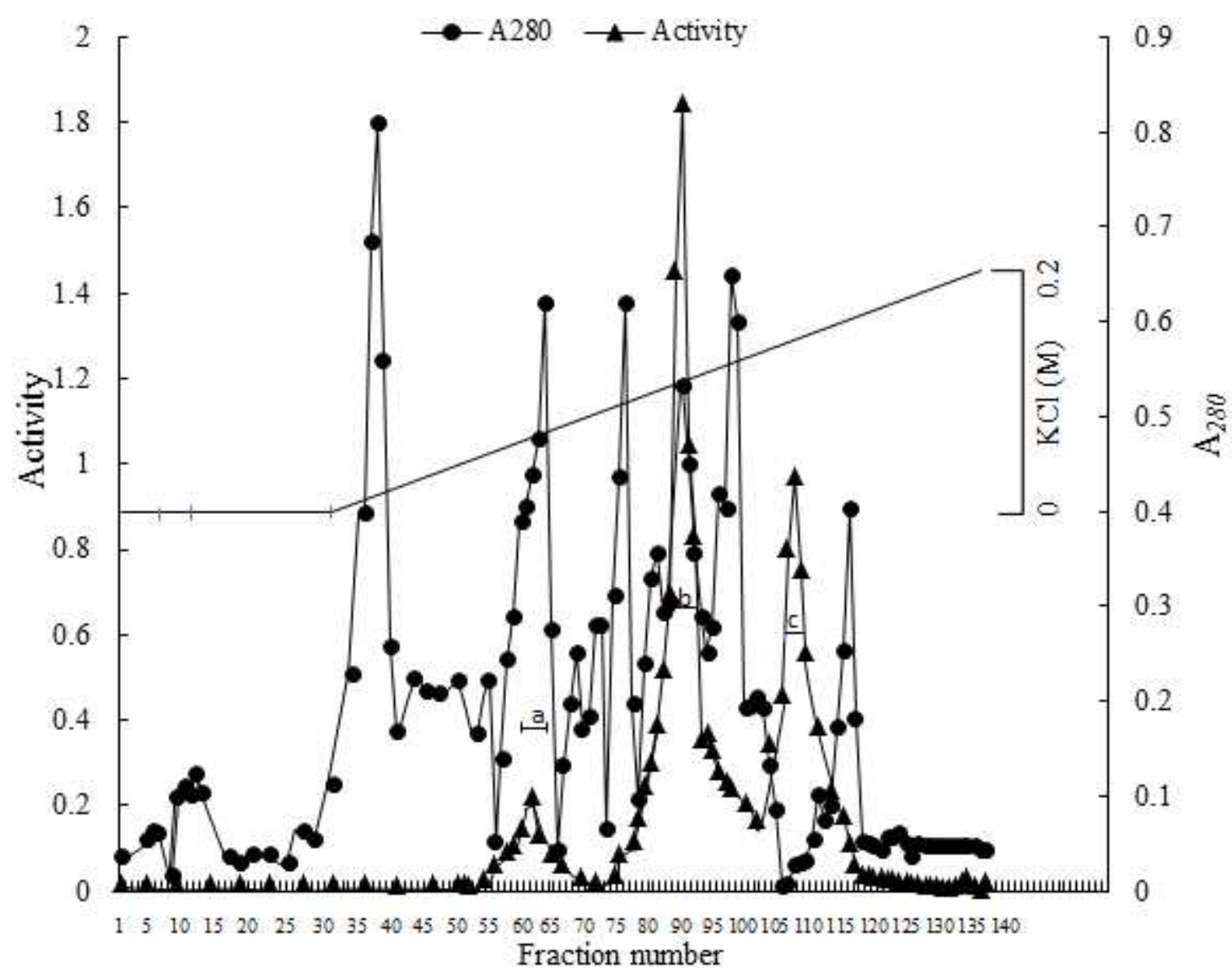

Fig. 3. A typical column chromatography of DEAE-cellulose of soluble proteins prepared from $150 \mathrm{~g}$ fresh onion bulb. For each fraction, absorbance at 280 $\mathrm{nm}(\bullet)$ and GST activity toward CDNB were determined. Activity ( $\mathbf{\Delta})$ is expressed as $\mu \mathrm{mol} \mathrm{min} \mathrm{m} \mathrm{ml}^{-1}$. Bars indicate the high active peak fractions of three onion GSTs. The fractions under the bar of GSTa, GSTb, GSTc peak were pooled for subsequent purification. The curve shows the concentration of KCl (0-0.2 M).

The high fractions containing high GST activity were collected from each peak and pooled for measuring their activities and proteins. Among them, GSTa contained $9.58 \%$ of total activity, while GSTb contain $61.45 \%$ and GSTc contained $28.97 \%$ (Table 2.).

Table 2. Elution pattern of component GSTs of onion bulb.

\begin{tabular}{lll}
\hline GSTs & Elution point (mM KCl) & \% of total activity \\
\hline GSTa & 67 & 9.58 \\
GSTb & 107 & 61.45 \\
GSTc & 140 & 28.97 \\
\hline
\end{tabular}

hexylglutathione-agarose to complete the purification. The GST was eluted with $1.8 \mathrm{mM} S$-hexylglutathione. Activities of the fractions and absorbance $A_{280}$ were taken. The active fractions were pooled and dialyzed in B buffer overnight and subjected to measure activity and protein. The summary of the purification is shown in Table 3. It was observed that in purification, GSTa, GSTb and GSTc had specific activities of 9075, 17259 and $19868 \mathrm{nmol} \mathrm{min}{ }^{-1} \mathrm{mg}^{-1}$ protein, respectively, along with yield 2.48, 3.17 and 1.28 and purification fold of $15.8,29.9$ and 34.5 , respectively.

The active GSTs pools were applied on a column of $S$ -

Table 3. Summary of purification of GSTs from onion bulb.

\begin{tabular}{|c|c|c|c|c|c|}
\hline Fraction & $\begin{array}{l}\text { Total activity } \\
\left(\mathrm{mmolmin}^{-1}\right)\end{array}$ & Total protein (mg) & $\begin{array}{l}\text { Specific activity (nmol min } \\
\mathrm{mg}^{-1} \text { protein) }\end{array}$ & Yield & Purification fold \\
\hline Crude protein & 174.2 & 302.3 & 576 & 100 & 1.00 \\
\hline$(\mathrm{NH} 4)_{2} \mathrm{SO}_{4} \mathrm{ppt}$ & 102.3 & 99.8 & 1025 & 58.7 & 1.78 \\
\hline \multicolumn{6}{|l|}{ DEAE-cellulose } \\
\hline GSTa & 6.67 & 8.05 & 825 & 3.83 & 1.43 \\
\hline GSTb & 42.8 & 5.85 & 7321 & 24.6 & 12.7 \\
\hline GSTc & 20.2 & 4.08 & 4949 & 11.6 & 8.50 \\
\hline \multicolumn{6}{|c|}{$S$-hexyl glutathione-agarose } \\
\hline GSTa & 4.81 & 0.53 & 9075 & 2.48 & 15.8 \\
\hline GSTb & 5.52 & 0.32 & 17259 & 3.17 & 29.9 \\
\hline GSTc & 2.38 & 0.12 & 19868 & 1.28 & 34.5 \\
\hline
\end{tabular}


The purities and molecular masses of the purified GSTs were examined by SDS-PAGE. The silver staining of the purified GSTa, GSTb and GSTc indicated that final product of GSTb and GSTc were highly purified and migrated as a single band on SDS-PAGE with an apparent molecular mass

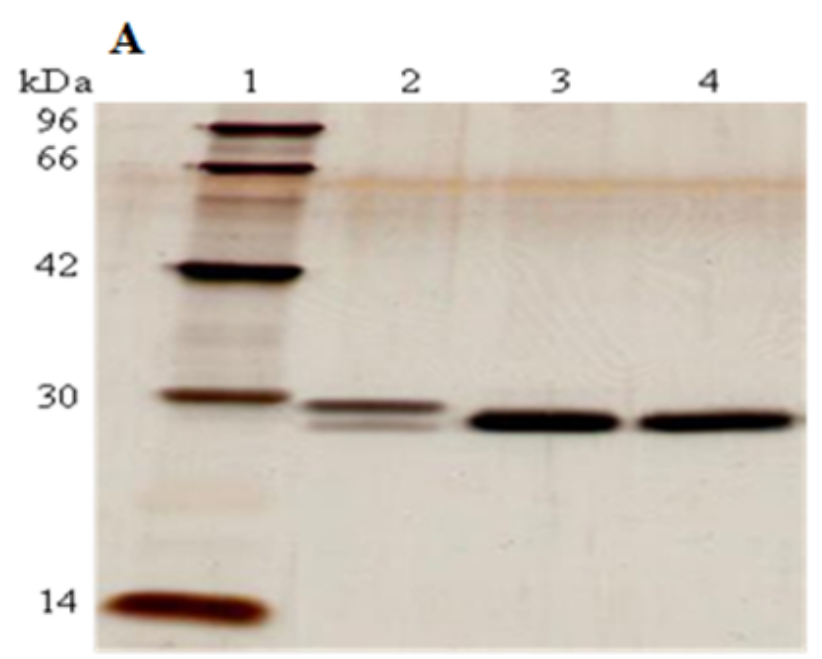

of $27 \mathrm{kDa}$ (Fig.4A). However, GSTa was found to have two adjacent protein bands within different molecular weight in SDS-PAGE. GSTa was further applied on a hydroxylapatite column chromatography. However, it did not produce better result.

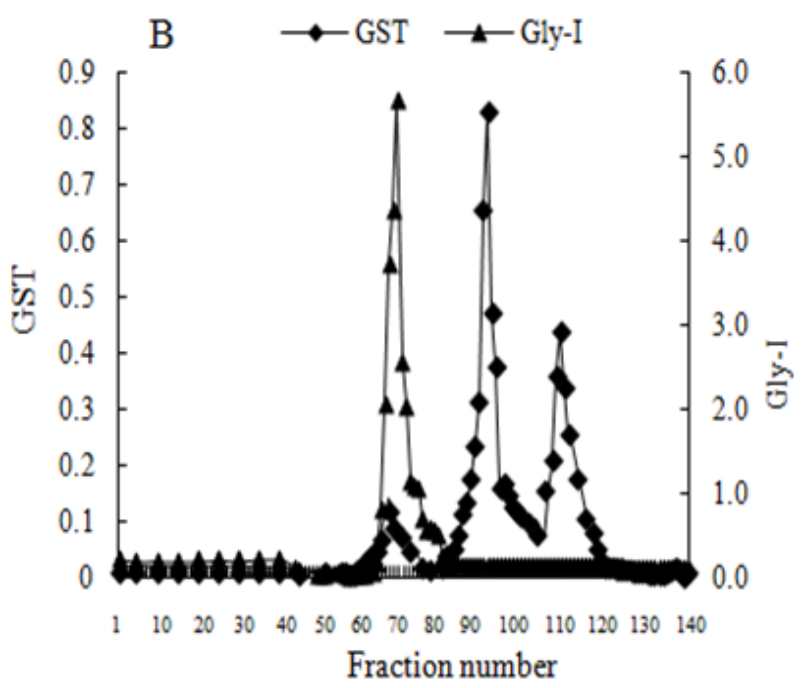

Fig. 4. Silver staining of different purified GSTs purification from onion bulb (A). Lane 1, Molecular weight marker; Lane 2, GSTa; Lane 3, GSTb; Lane 4, GSTc. Elution profile of GSTs anf Gly-I from affinity column chromatography (B). For each fraction, absorbance at $280 \mathrm{~nm}$ and GST activity ( $\mathbf{\Delta}$ ) and Gly-I activity ( )were determined. Activitiesof GST and Gly-I areexpressed as $\mu \mathrm{mol} \mathrm{min}^{-1} \mathrm{ml}^{-1}$.

Previously, another detoxification enzyme Glyoxalase-I (Gly-I) was purified using similar chromatographies like DEAE and $S$-hexylglutathione-agarose, and in elution of GlyI, $\mathrm{KCl}$ and $S$-hexylglutahione were used [12]. In this study, we also used those chromatographies as well as $\mathrm{KCl}$ and $S$ hexylglutahione for GST elution. Therefore, we checked the Gly-I activities in the DEAE fractions. Interestingly, a Gly-I peak eluted with similar $\mathrm{KCl}$ concentration where GSTa eluted, and both GST and Gly-I activities were found in same fraction (Fig. 4B). Therefore, either of the adjacent protein bands in SDS-PAGE will be a GST, and another will be Gly-I protein.

\section{Conclusion}

In conclusion, this study reported comparative GST activities in a good number of crops. The onion seedlings showed the highest GST activities as compared to others. It is also suggested that some of the crops have not yet been searched for GST which could be important sources of GST with important biological role under biotic and abiotic stresses. Local onion cultivar BARI onion-4 contained three GSTs among which, GSTb and GSTc could be purified by consecutive use of DEAE-cellulose and affinity chromatography. GSTa needed more methodological application for its purification.

\section{Acknowledgement}

The authors are grateful to Improvement and Quality Seed production of Rice, Wheat and Maize Project, Ministry of Agriculture, Bangladesh for financial support.

\section{References}

[1] Edwards R, Dixon PD, Walbat V. 2000. Plant glutathione $S$ transferases: enzymes with multiple functions in sickness and inhealth. Trends Plant Sci 5: 193-198.

[2] Dean VJ, Devarnne PT, Ik-Soo L, Orlofsky EL. Properties of a maize glutathione $S$-transferase that conjugates coumaric acid and other phenylpropanoids. 2005. Plant Physiol 108: 985-994

[3] Bilang K, Widersten M, Engström A, Kozarich JH, Mannervik B. 1993. Detoxification of base propenals and other $\alpha, \beta-$ unsaturated aldehyde products of radical reactions and lipid peroxidation by human glutathione transferases. Proc. Natl. Acad. Sci. USA 91:1480-1484.

[4] Gonneau J, Mornet R, Laloue AM. 1998. Nicotiana plumbaginifolia protein labeled with an azidocytokininagonist is a glutathione $S$-transferase. Physiol Plant 103: 114-124.

[5] Loyall L, Uchida Braun KS, Furuya M, Frohnmeyer H. 2000. Glutathione and a UV light-induced glutathione $S$-transferase are involved in signaling to chalcone synthase in cell cultures. Plant Cell 12: 1939-1950.

[6] Dixon PD, Lapthorn A, Edwards R. 2002. Plant glutathione transferases. Genome Biol 3(3): 1-10.

[7] Mohsenzadeh S, Esmaeili M, Moosavi F, Saffariand B, Mohabatkar H. 2011. Plant glutathione $S$-transferase classification, structure and evolution. African Journal Biotechnol 10(42): 8160-8165. 
[8] Müller LA, Goodman CD, Silady RA, Walbot V. 2000. AN9, a petunia glutathione $S$-transferase required for anthocyanin sequestration, is a flavonoid-binding protein. Plant Physiol, 123: $1561-1570$.

[9] Noctor G, Mhamdi A, Chaouch S, Han Y, Neukermans J, Marquez B, Queval G,. Foyer C H. 2012. Glutathione in plants: an integrated overview. Plant Cell Environ 35: 454-484.

[10] Blokhina KJM, Van der Zaal BJ, Velterop J, Quint AB, Mennes AM, Hooykaas PJ, Libbenga KR. 2003. Further characterization of expression of auxin-induced genes in tobacco (Nicotiana tabacum) cell-suspension cultures. Plant Physiol 102: 513-520.

[11] Rohman MM, Hossain MD, Suzuki T, Takada G, Fujita M. 2009. Quercetin-4'-glucoside: aphysiological inhibitor of the activities of dominant glutathione $S$-transferases in onion (Allium cepa L.)bulb.” Acta Physiol. Plant 31: 301-309.

[12] Hossain MA, Fujita M. 2009. Purification of Glyoxalase I from onion bulbs and molecular cloning of its cDNA. Biosci. Biotechnol. Biochem 73 (9): 2007-2013.

[13] Bradford MM. 1976. A rapid and sensitive method for the quantitation of microgram quantities of protein utilizing the principle of protein-dye binding. Anal Biochem 72: 248-254.

[14] Laemmli UK. 1970. Cleavage of structural proteins during the assembly of head of bacteriophage T4. Nature 227: 680-685.

[15] Dixon PD, Davis GB, Edwards R. 2002. Functional divergence in the glutathione transferase superfamily in plants. J Biol. Chem 277: 30859-30869.

[16] Frova C. 2003. The plant glutathione transferase gene family: genomic structure, functions, expression and evolution." Physiol.Plantarum 119(4): 469-479.

[17] Cummins I, Cole JD, Edwards R. 1999. A role for glutathione transferases functioning as glutathione peroxidasesin resistance to multiple herbicides in black-grass. Plant Journal 18: 285-292.

[18] Kunieda T, Fujiwara T, Amano T, Sioihi Y. 2005. Molecular cloning and characterization of a senescence-induced tau-class glutathione $S$-transferase from barley leaves. Plant Cell Physiol 46: 1540-1548.

[19] Levine A, Tenhaken R, Dixon R, Lamb C. 1994. $\mathrm{H}_{2} \mathrm{O}_{2}$ from the oxidative burst orchestrates the plant hypersensitive disease resistance response. Cell 79: 583-593.

[20] Kim SG, Kim ST, Kang SY, Wang Y, Kim W, Kang KY. 2008. Proteomic analysis of reactive oxygen species (ROS)-related proteins in rice roots. Plant Cell Rep 27: 363-375.

[21] Kiyosue T, Yamaguchi-Shinozaki K, Shinozaki K, 1993. Characterization of two cDNAs (ERD11 and ERD13) for dehydration inducible genes that encode putative glutathione $S$-transferases in Arabidopsis thaliana L. FEBS Lett 335: 189192.

[22] Liu X, Deng Z, Gao S, Sun X, Tang K. 2007. Molecular cloning and characterization of a glutathione $S$-transferase gene from Ginkgo biloba. DNA Seq 18: 371-379.

[23] Anderson JV, Davis DG. 2004. Abiotic stress alters transcript profiles and activity of glutathione $S$-transferase, glutathione peroxidase, and glutathione reductase in Euphorbia esula. Physiol. Plant 120: 421-433.
[24] Nutricati E, Miceli A, Blando F, Bellis De L. 2006. Characterization of two Arabidopsis thaliana glutathione $S$ transferases. Plant Cell Rep 25: 997-1005.

[25] Ezaki B, Yamamoto Y, Matsumoto H. 1995. Cloning and sequencing of the cDNAs induced by aluminum treatment and $\mathrm{Pi}$ starvation in cultured tobacco cells. Physiol. Plant 93: 1118.

[26] Sharma KY, Davis RK. 1994. Ozone-induced expression of stress related genes in Arabidopsis thaliana. Plant Physiol 105: 1089-1096.

[27] Ezaki B, Suzuki M, Motoda H, Kawamura M, Nakashima S, Matsumoto H. 2004. Mechanism of gene expression of Arabidopsis glutathione $S$-transferase, AtGST1, and AtGST11 in response to aluminum stress. Plant Physiol 134: 1672-1682.

[28] Marrs AK. 1996. The functions and regulation of glutathione $S$-transferasesinplants. Annu. Rev. Plant Physiol. Plant Mol. Biol 47: 127-158.

[29] Zhou J, Goldsbrough BP. 1993. An Arabidopsis gene with homology to glutathione $S$-transferase is regulated by ethylene. Plant Mol. Biol 22: 517-523.

[30] Takahashi Y, Nagata T. 1992. parB: an auxin-regulated gene encoding glutathione $S$-transferase. Proc Natl. Acad. Sci. USA 89: $56-59$.

[31] Wagner U, Edwards R, Dixon PD, Mauch F. 2002. Probing the diversity of the Arabidopsis glutathione $S$-transferase gene family. Plant Mol. Biol 49: 515-532.

[32] Xu F, Lagudah SE, Moose PS, Riechers ED. 2002. Tandemlyduplicated safener-induced glutathione $S$-transferase genes from Triticum tauschii contribute to genome- and organ-specific expression inhexaploid wheat. Plant Physiol 130: $362-373$.

[33] Chen J-H, Jiang H-W, Hsieh E-J, Chen H-Y, Chien C-T, Hsieh H-L, Lin T-P. 2012. Drought and salt stress tolerance of Arabidopsis glutathione $S$-transferase U17 knockout mutant are attributed to the combined effect of glutathione and abscisic acid. Plant Physiol158(1): 340-351.

[34] Liu D. Liu Y, Rao J, Wang G, Li H, Ge F, Chen C. 2013. Over expression of the glutathione $S$-transferase gene from Pyrus pyrifolia fruit improves tolerance to abiotic stress in transgenic tobacco." Plant Mol. Biol 47(4): 515-523.

[35] Kwon S-H, Kwon H-K, Kim W, Noh WE, Kwon M, Choi YI. 2014. Identification of salt and drought inducible glutathione $S$-transferase genes of hybrid poplar. J. Plant Biotechnol 41: 26-32.

[36] Rohman MM, Begum S, Akhi HA, Ahsan SMFA, Uddin SM, Amiruzzaman M, Banik BR. 2015. Protective role of antioxidants in maize seedlings under saline stress: Exogenous proline provided better tolerance than betaine. Bothalia 45: 17-35.

[37] Rohman MM, Hossain AM, Fujita M. 2010. Levels of a dominant glutathione $S$-transferase in onion bulbs have a seasonal relationship with physiological inhibitors. Aust. J. Crop Sci 4(1): 55-62.

[38] Rezaei K. M, Shobbar S-Z, Maryam S, Abedini R, Sajjad Z. 2013. Glutathione $S$-transferase (GST) family in barley: Identification of members, enzyme activity, and gene expression pattern. J Plant Physiol 170: 1277-1284. 
[39] Hu T. 2014. A glutathione $S$-transferase confers herbicide tolerance in rice." Crop Breed. Applied Biotechnol 14: 76-81.

[40] Sharma R, Sahoo A, Devendran R, Jain M. 2014. Overexpression of a rice Tau class glutathione $S$-transferase gene improves tolerance to salinity and oxidative stresses in Arabidopsis.’DOI: 10.1371/journal.pone.0092900.

[41] Scarponi L, Quagliarini E, Del DB. 2006. Induction of wheat and maize glutathione $S$-transferase by some herbicide safeners and their effect on enzyme activity against butachlor and terbuthylazine. Pest Manage Sci 62(10): 927-32.

[42] Galle A, Csiszar J, Seceji M, Tari I, Guoth A. Gyorgyey J. Erdei L. 2008. Monitoring the levels of phi and tau group GST genes in wheat cultivars under osmotic stress."Acta Biologica Szegediensis 52(1): 95-96.

[43] Pandey B, Sharma P, MPandey D, Varshney J, Sheoran S, Singh M, Singh R, Sharma I, Chatrath R. 2012. Comprehensive computational analysis of different classes of Glutathione $S$-transferases in Triticum aestivum L. Plant Omics Journal 5(6): 518-531.

[44] Marrs KA, Alfenito MR, Lloyd AM, Walbot V. 1995. A glutathione $S$-transferase involved in vacuolar transfer encoded by the maize gene Bronze-2. Nature 375(6530): $397-$ 400 .

[45] Cetinka H, Seckindinler B, Tascicetinya E, Dinler SB, Tasci E. 2014. Investigation of comparative regulation on antioxidant enzyme system under copper treatment and drought stress in maize (Zea mays L.). Not. Bot. Horti. Agrobot 42(2): 363-371.

[46] Marrs AK, Walbot V. 1997. Expression and RNA splicing of the maize glutathione $S$-transferase Bronze2 gene is regulated by cadmium and other stresses. Plant Physiol 1997. 113: 93102.

[47] Hossain MA, Mostofa GM, Fujita M. 2013. Heat-shock positively modulates oxidative protection of salt and droughtstressed mustard (Brassica campestris L.) seedlings. Journal Plant Sci. Mol. Breed http://www.hoajonline.com/journals/pdf/2050-2389-2-2.pdf, doi: $10.7243 / 2050-2389-2-2$.

[48] Kapoor D, Kaur S, Bhardwaj R. 2014. Physiological and biochemical changes in Brassica juncea plants under Cdinduced stress. BioMed Research International. Article ID 726070, http://dx.doi.org/10.1155/2014/726070.

[49] Shahram N, Shahrokh N, Hossein K. 2012. Induction of phytochelatin and responses of antioxidants under cadmium stress in safflower (Carthamus tinctorius) seedlings. Turkish Journal of Botany 36: 495.

[50] Chan C, Lam M-H. 2014. A putative lambda class glutathione $S$-transferase enhances plant survival under salinity stress. Plant Cell Physiol 55(3): 570-579.

[51] Dinler SB, Antoniou C, Fotopoulous V. 2014. Interplay between GST and nitric oxide in the early response of soybean (Glycine max L.) plants to salinity stress. Journal Plant Physiol 171(18): 1740-7.

[52] Dalton D, Boniface C, Turner Z, Lindahl A, Kim JH, Jelinek L, Govindarajulu M, Finger ER, Taylor GC. 2009. Physiological roles of glutathione $S$-transferases in soybean root nodules. Plant Physiol 150: 521-530.
[53] Talukder D. 2012. An induced glutathione-deficient mutant in Grass pea (Lathyrus sativus L.) Modification of plant morphology, Alternations in antioxidants activities, and increased sensitivity to Cadmium. Bioremediation. Biodiversity and Bioavailability 6: 75-86.

[54] Dixit V, Pandey V, Shyam R. 2001. Differential antioxidative responses to cadmium in roots and leaves of pea (Pisum sativum L. cv. Azad). Journal Exp. Bot 52: 1101-1109.

[55] Nahar K, Hasanuzzaman M, Alam MM, Fujita M. 2015. Exogenous glutathione confers high temperature stress tolerance in mung bean (Vigna radiata L.) by modulating antioxidant defense and methylglyoxal detoxification system. Environmental and Experimental Bot 112: 44-54.

[56] Hossain MA, Hasanuzzaman M, Fujita M. 2011. Coordinate induction of antioxidant defense and glyoxalase system by exogenous proline and glycine betaine is correlated with salt tolerance in mung bean. Front. Agric. China 5(1): 1-14.

[57] Molla RM, Ali MR, Hasanuzzaman M, Mamun AHM, Ahmed A, Nazimuddowla NAM, Rohman MM. 2014. Exogenous proline and betaine-induced upregulation of glutathione transferase and glyoxalase I in lentil (Lens culinaris ) under drought stress. Not. Bot. Horti. Agrobo 42(1): 73-80.

[58] Gazendam I, Oelofse D. 2007. Isolation of cowpea genes conferring drought tolerance: construction of a cDNA drought expression library. Water SA 33(3): 387-391

[59] Hossain ZM, Fujita M. 2003. Modulation of pumpkin glutathione $S$-transferases by aldehydes and related compounds. Plant Cell Physiol 44(5): 481-490.

[60] Hossain ZM, Fujita M, "Purification of a phi-type glutathione $S$-transferase from pumpkin flowers, and molecular cloning of its cDNA. Biosci. Biotech.Biochem 66(10): 2068-76.

[61] Hahn K, Strittmatter G. 1994. Pathogen-defence gene prpl-1 from potato encodes an auxin-responsive glutathione $S$ transferase. Eur. J. Biochem 226: 619-626.

[62] Peil D, Jinping D, Zilei D, Meng L, Yiyang F, Chengwei L. 2012. Cloning and expression of a tomato glutathione $S$ transferase (GST) in Escherichia coli. African Journal Biotechnol 11(23): 6402-6408.

[63] Csiszar J, Horvath E, Vary Z, Galle A, Bela K, Burnner S, Tari I. 2014. Glutathione transferase supergene family in tomato: Salt stress-regulated expression of representative genes from distinct GST classes in plants primed with salicylic acid. Plant Physiol and Biochem 78: 15-26.

[64] Kumchail J, Huang J-Z, Lee C-Y, Chen F-C, Chin S-W. 2012. Proline partially overcomes excess molybdenum toxicity in cabbage seedlings grown in vitro. Genet. Mol. Res 12: 55895601.

[65] Huang S-S, Hung J-H, Chiu S-C, Chen J-H, Lin S-S, Lin C-Y, Yi C-H, Huang J-G, Iy H-L. 2009. Sweet potato trypsin inhibitor with thioltransferase-like and glutathione $S$ transferase-like activities. Botanical Studies 50: 443-450.

[66] Gong H, Jiao Y, Hu WW, Pua CE 2005. Expression of glutathione $S$-transferas and its role in plant growth and development in vivo and shoot morphogenesis in vitro. Plant Mol. Biol 57: 53-66. 